\title{
Symposium on Complex Ankle Fractures
}

\author{
Alexandre L Godoy-Santos ${ }^{1}$, German M Joannas ${ }^{2}$ \\ Journal of Foot and Ankle Surgery (Asia Pacific) (2021): 10.5005/jp-journals-10040-1198
}

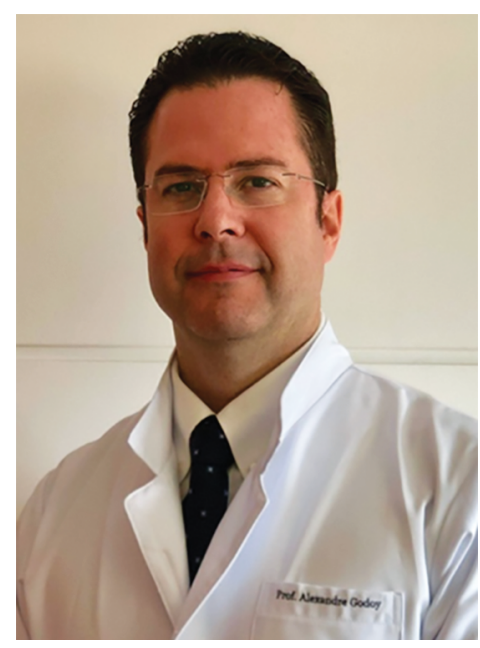

Alexandre Leme Godoy-Santos

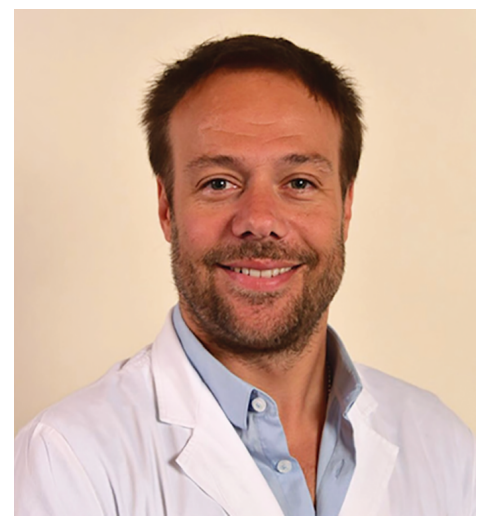

German M Joannas
The term "complex trauma of the foot and ankle" is generally reserved for fractures with joint invoIvement, associated with soft tissue damage, vascular and nerve lesions showing high risk of complications in the short, medium, and long follow-up. Despite advances in understanding and better options of management, malleolar fractures are often underestimated, and the prognosis becomes worsened. This is a complex segment of the human body, and it is imperative to understand that injuries here represent a disruption of what is now perceived to be a "ring" like disruptions elsewhere, maybe in the pelvis. These injuries demand significant respect for the principles of surgical treatment, and a significant number of patients continue to experience poor functional results despite what is thought to be adequate management. The main complication following ankle fracture is osteoarthritis, and this may even occur when the injury is initially perceived to be small and not complex ${ }^{1}$ adding to the difficulty.

Some soft tissue injuries are now better defined at the time of ankle trauma; many were missed and the emphasis on the overall assessment of an injured ankle, not focusing on the instability caused only by the fracture is now being increasingly recognized. Advances in early tissues damage identification and surgical treatment techniques allow better clinical outcomes to be achieved. ${ }^{2}$

In recent decades, the literature indicates three key factors that improve functional results.

The first factor is to pursue the best reduction of both the articular surface and the fracture guided not only by direct control but also by arthroscopy and 2D and 3D intraoperative imaging.

The second factor is to identify residual instabilityespecially deltoid and syndesmosis - to treat it through ligament reconstructions with or without augmentation.
${ }^{1}$ Department of Orthopedic Surgery, University of São Paulo, R. Dr Ovídio Pires de Campos, São Paulo, Brazil

${ }^{2}$ Department of Orthopaedics, Esp. Pierna, Tobillo y Pie, Instituto Dupuytren, Cepp From Buenos Aires, Argentina

Corresponding Author: German M Joannas, Department of Orthopaedics, Esp. Pierna, Tobillo y Pie, Instituto Dupuytren, Cepp From Buenos Aires, Argentina, Phone: +5491149400206, e-mail: germanjoannas@icloud.com

How to cite this article: Godoy-Santos AL, Joannas GM. Symposium on Complex Ankle Fractures. J Foot Ankle Surg (Asia Pacific) 2021;8(4):157.

Source of support: Nil

Conflict of interest: None

More recently, the literature shows the third factor: the role of the inflammatory environment in the continuing aggression to intra-articular tissues-synovial tissue, synovial fluid and chondral tissue - and begins to propose therapeutic options to minimize it. ${ }^{3}$

The present issue of JFAS (AP) carries a symposium that was designed to cover various aspects of these complex injuries; we have tried to get experts to discuss the state-of-the-art options in management. The topics range from malleolar fractures management, the complications, and innovations in this field, as well as technical tips that are based on the current literature and the expert opinion of the authors.

Key topics are Weber B ankle fracture treatment updates, pathomechanics and fixation options for ligament injuries, open fractures and ankle dislocations management, intraoperative C-arm CT for assessment of joint reduction, early detection and experimental therapies to inhibit progression to osteoarthritis and primary tibio-talo-calcaneal arthrodesis in malleolar fractures.

The editors hope that this comprehensive collection would add to the knowledge of the readers and aid them in taking the correct decisions in managing their cases.

\section{References}

1. Delco ML, Kennedy JG, Bonassar LJ, et al. Post-traumatic osteoarthritis of the ankle: a distinct clinical entity requiring new research approaches. J Orthop Res 2017;35(3):440-453. DOI: 10.1002/jor. 23462.

2. Wang X, Zhang C, Yin JW, et al. Treatment of medial malleolus or pure deltoid ligament injury in patients with supination-external rotation type IV ankle fractures. Orthop Surg 2017;9(1):42-48. DOI: 10.1111/ os.12318.

3. Pham TM, Kristiansen EB, Frich LH, et al. Association of acute inflammatory cytokines, fracture malreduction, and functional outcome 12 months after intra-articular ankle fracture-a prospective cohort study of 46 patients with ankle fractures. J Orthop Surg Res 2021;16(1):338. DOI: 10.1186/s13018-021-02473-8.

(c) The Author(s). 2021 Open Access This article is distributed under the terms of the Creative Commons Attribution 4.0 International License (https://creativecommons. org/licenses/by-nc/4.0/), which permits unrestricted use, distribution, and non-commercial reproduction in any medium, provided you give appropriate credit to the original author(s) and the source, provide a link to the Creative Commons license, and indicate if changes were made. The Creative Commons Public Domain Dedication waiver (http://creativecommons.org/publicdomain/zero/1.0/) applies to the data made available in this article, unless otherwise stated. 